\title{
PUISI SEBAGAI MEDIA PENGINJILAN
}

\author{
Wirol O. Haurisssa
}

\begin{abstract}
Preaching gospel is good news, because it is not only based on Christian values but also on universal Christian values, namely love. This background attracts my attention to analyze the poetry of Duang e, by looking at the relation between poetry texts and the function of poetry as an evangelistic medium. This poem is a representation of universal values choice from theological aesthetics and concrete aesthetics of empirical reality. In addition, there are elements of contextual values of culture, religion, and all elements of social values, dimensions of life, humanity, nature, and God. This research uses analysis model of semiotics in missiology studies that focus on text and creative experience, emotional side of texture. It aims to understand and express the meaning, to give values sign of the sign text, signifer, and sign systems that are in the medium of language, and working on the text in a sign construction, while poetry always changes in line with the evolution of tastes. Fokkelman emphasized that poetry had covered Bible literature all this time, those are the entire book of Psalms, Proverbs, Song of Songs, Lamentations, Job, Prophets. There are also poems that tell history, from Genesis to the books of Kings (Genesis 49, Deuteronomy 31; 32, Judges 5, Exodus 15, I Samuel 2: 1-10, II Samuel 1: 19-27, II Samuel 22).

The research uses qualitative method. The location of research is around Ambon City. The primary source is poems that will be classified, while results of interviews and book that related to this research as secondary source. The author concludes from this paper that the medium of communication is not on a subject from normal academic understanding, but the multidisciplinary study area of the evangelistic imperative values that becomes meaningful, and unit of gospel value that related to the aesthetics of the creation of the whole creation. The aim is to realize the Kingdom of God as joyful news without any gaps and barriers in the aesthetic series of God's work, as well as the real nature of God's divinity in church's mission.
\end{abstract}

Keywords: Poetry, Media, Evangelism, Semiotics, Missiology

\begin{abstract}
Abstrak
Pemberitaan Injil adalah kabar baik, karena tidak hanya didasarkan pada nilai-nilai kristen semata melainkan juga nilai-nilai kristen yang bersifat universal, yaitu cinta kasih. Ini merupakan latar belakang yang menarik perhatian saya untuk menganalisis puisi Duang e, dengan melihat hubungan antara teks puisi dan fungsi puisi sebagai media penginjilan. Puisi ini merupakan representasi pilihan nilai universal dari estetika teologis dan estetika konkret realitas empiris. Selain itu, ada unsur nilai kontekstual budaya, agama, dan seluruh anasir nilai-nilai sosial, dimensi hidup, manusia, alam, dan Allah. Model analisis yang digunakan adalah semiotika dalam studi misiologi yang berfokus pada teks dan pengalaman kreatif, sikap emosional tekstur. Ini bertujuan untuk memahami dan mengungkapkan makna, memberikan nilai-nilai pertanda dari teks tanda, penanda, dan sistem tanda yang ada di dalam medium bahasa, serta menggarap teks pada
\end{abstract}


suatu konstruksi tanda, sedangkan puisi selalu berubah-ubah sejalan dengan evolusi selera. Fokkelman menegaskan bahwa selama ini puisi sudah mewarnai literatur sastra Alkitab, yaitu seluruh kitab Mazmur, Amsal, Kidung Agung, Ratapan, Ayub, Nabi-Nabi. Ada pula puisi-puisi yang berkisah tentang sejarah, mulai dari kitab Kejadian sampai kitab Raja-Raja (Kejadian 49, Ulangan 31; 32, Hakim-Hakim 5, Keluaran 15, I Samuel 2: 1-10, II Samuel 1: 19-27, II Samuel 22).

Penelitian ini menggunakan metode penelitian kualitatif. Lokasi penelitian di sekitar Kota Ambon. Penelitian dilakukan selama satu bulan. Sumber data utama (primer) adalah puisi yang akan diklasifikasi, sedangkan hasil-hasil wawancara dan buku-buku yang berhubungan dengan penelitian sebagai sumber sekunder. Penulis menyimpulkan dari tulisan ini bahwa media komunikasi tidak pada satu subjek dari pengertian akademik yang normal, tetapi area studi multidisipliner nilai-nilai imperatif penginjilan yang diartikulasikan menjadi bermakna, dan satuan nilai Injil yang berhubungan dengan estetika penciptaan seluruh ciptaan. Tujuannya untuk mewujudkan Kerajaan Allah sebagai kabar baik tanpa ada sekat dan pembatas dalam rangkaian estetika karya Allah, serta sifat keilahian Allah yang nyata dalam misi gereja.

Kata Kunci: Puisi, Media, Penginjilan, Semiotik, Misiologi

\section{LATAR BELAKANG}

Gereja dalam praktisnya merupakan kesatuan dengan pemberitaan Injil yang adalah kabar baik, "sukacita" berdasarkan nilai dan ajaran kekristenan. Berdasarkan pikiran tersebut, Injil dalam konsep Matius, Markus, Lukas dan Yohanes yang mengajarkan nilai yang dimiliki semua manusia. Peneliti memfokuskan perhatian pada nilai universal, yaitu cinta kasih. Artinya, memberitakan nilai cinta kasih sama dengan menginformasikan kemerdekaan iman dalam segala keteraturan dan kebebasan hidup yang menyatakan kekuatan untuk terlepas dari belenggu penindasan dan keterpurukan. Dari situlah tindakantindakan Injil dapat melawan kekuasaan yang otoriter dan untuk menunjukkan kesejatian iman dalam membangun kembali keharmonisan antara relasi manusia dan Allah, manusia dan manusia, manusia dan alam. Demikian dapat dilihat bahwa adanya nilai keharmonisan yang mengarahkan manusia membangun moralitas untuk bebas dari penindasan psikologis, masalah-masalah sosial, ekonomi, politik, dan budaya.

Di sisi lain, pekabaran Injil mengharuskan gereja membangun instrumeninstrumen nilai cinta kasih. Salah satu instrumennya adalah puisi sebagai media penginjilan (pekabaran Injil) yang mengandung nilai-nilai Injil universal kepada 
semua penerima pesan dari stansmitter yang adalah gereja itu sendiri. Pernyataan tersebut bagi peneliti sangatlah penting, bahwa Injil dapat diberitakan dari puisi yang dipandang sebagai sebuah kabar baik yang diorientasi ke dalam media penginjilan dengan tujuan pembaharuan. Lebih lanjut, puisi sebagai karya sastra mampu untuk menjawab bagaimana kabar baik itu ditemukan bersama nilai-nilai Injil yang hidup dalam puisi. Maksudnya, puisi yang merupakan bentuk dari karya sastra dapat berbicara soal nilai-nilai pemeliharaan tanpa harus menghapuskan Alkitab sebagai media sentral. Bagi peneliti, media penginjilan apa pun harus mampu mendialogkan dirinya dengan Alkitab yang menjadi nafas Injil.

Pada puisi, pembaca dapat menemukan estetika Injil untuk membangun dan memelihara nilai-nilai kemanusiaan secara teratur demi menjelaskan apa yang manusia percaya. Terutama estetika teologi dan estetika konkritsitas yang semuanya dituangkan dalam bahasa puisi dengan memunculkan nilai-nilai kontekstual berdasarkan budaya, agama dan seluruh anasir nilai-nilai sosial. Selain itu, tidak dapat dihindari bahwa selamanya satu kausalitas utama bahwa manusia harus menyatakan realitas kepercayaannya dan tindakannya dalam melihat, mendengar, merasakan, menuturkan, dan melakukan, sehingga puisi pada posisinya dapat menjadi jalan dan pilihan lain untuk mewujudkan keterhubungan Injil dan kayakinan.

Penelitian ini juga berupaya untuk menemukan pilihan-pilihan kata sebagai pilihan nilai yang dituangkan oleh penyair dari realitas kayakinannya menjadi pemberian Injil dan menemukan objek puisi Duang $e$ yang mengandung esntitas budaya Kei dengan realitas kayakinan beragama. Selain itu, peneliti akan melihat hubungan puisi dan Injil bersama sifat-sifat teologis di dalam dunia kesusastraan lokal mampu menjadi produk pemberitaan seperti judul puisi yaitu Duang e yang artinya Tuhan dimetaforkan oleh penyair sebagai upaya penyeimbangan antara pembaca dan keyakian yang dikategorikan dengan ketidakeyakian penerima pesan dalam realitas teologis kekristenan. Ditambahkan pula, peneliti akan melihat corak bahasa lokal yang merupakan salah satu sistem dari bahasa kepercayaan masyarakat (adat) Kei bersamaan dengan keyakinan mereka bahwa Duang $e$ membentuk nilai dari penyembuhan, penghiburan, perdamaian, kebahagiaan, penghormatan, dan penyembahan tertinggi. 
Lebih rinci, tujuan dari puisi dan Injil yang menggunakan puisi Duang $e$ akan menampilkan kandungan nilai-nilai Injil yang universal, kualitas sastra dan kualitas teologis dari kata-katanya menjadi media penginjilan dan kekuatan bahasa bagi gereja. Di mana Injil harus terus berkembang dengan keindahannya yang ada pada nilai cinta kasih dalam seluruh realitas pembaca, penulis, dan penerima pesan. Hal ini menunjuk pada temuan dasar missiologi dengan merumuskan pertanyaan, apakah puisi Duang e mengandung nilai-nilai Injil dan bagaimana puisi dapat digunakan sebagai media penginjilan di tengah perkembangan zaman.

\section{KAJIAN PUSTAKA}

Kajian pustaka berdasarkan pada puisi, semiotika, media, dan penginjilan yang didekripsikan sebagai berikut:

\section{* Puisi}

Hakekat puisi adalah keindahan gaya bahasa, menurut Rene Wellek dan Werren, puisi memiliki kekuasaan fungsi seni, unsur-unsur estetika, dan kekuasaan gaya bahasa dalam kalimat dan baris. Riffaterre menyatakan puisi selalu berubah-ubah sesuai dengan evolusi selera dan perubahan konsep estetikanya. Puisi merupakan ekspresi tidak langsung yang disebabkan oleh penggantian arti (displacing of meaning), penyimpanan arti (distrorting of meaning) dan penciptaan arti (creating of meaning). ${ }^{1}$ Wellek menyatakan, "poetika" atau ilmu sastra, sesungguhnya hanya memiliki satu istilah yaitu "puisi". Istilah puisi mencakup prosa. ${ }^{2}$ Poetry adalah bentuk penyebutan puisi dalam bahasa inggris disebut poem, sedangkan prosa merupakan narasi estetika dengan tidak atau mengikuti tata bahasa normatif. ${ }^{3}$ Preminger, menyatakan makna puisi adalah arti dari arti (meaning of meaning) atau makna "significance". 4 Pergantian arti berdasarkan pada penggunaan bahasa kiasan (figuratif language) meliputi semile, personifikasi, metafora dan metonimi. ${ }^{5}$ Shahnon Ahmad mengemukakan bahwa dalam puisi terdapat unsur-unsur emosi, imajinasi, pemikiran, ide, nada, irama, kesan pancaindra, susunan kata, kata-kata kiasan, kepadatan, dan perasaan yang bercampur-baur menjadi tiga unsur penting yaitu "pemikiran, ide dan kesan". Pencetus definisi puisi berkembang juga dari Taylor Coleridge. Taylor mengemukakan puisi adalah kata-kata terindah dengan susunan 
terindah, sedangkan Carlyle mengemukakan puisi sebagai pemikiran musikal. Musikal berarti penyair dalam kaitannya dengan menciptakan puisi harus memikirkan "kemerduan bunyi” puisi (harmoni music), yaitu mengungkapkan “orkestrasi puisi”. Lain dari Wordsworth, puisi adalah pernyataan perasaan yang imajinatif yaitu perasaan yang direkakan atau diangankan. Dari Auden, ia menjelaskan bahwa puisi merupakan campur-baurnya pernyataan yang bersifat konkret dan artistik dalam bahasa emosional serta berirama. ${ }^{6}$

Beberapa pendekatan tentang puisi dihubungkan dengan karakteristik Jan Fokkelman, seorang sastrawan (pakar puisi Alkitab) dunia sastra Biblis yang mendefenisikan puisi dalam kaitannya dengan puisi Ibrani klasik. Menurutnya puisi adalah hasil (di satu pihak) penggunaan bahasa, gaya dan struktur secara seni, dan (di lain pihak) memberikan kesenjangan yang ditetapkan pada tingkattingkat teks, sehingga tercipta kombinasi teratur antara bahasa dan angka. Puisi adalah segala hal yang dapat dibandingkan. Ia tidak hanya sibuk memberikan bentuk pada pesan yang rumit dengan pilihan sarana bahasa yang cermat. Di dalam puisi Ibrani klasik, ia memperhatikan keseimbangan dalam teksnya. Apakah bagian baris bersamaan dengan satu ayat tertentu? Apakah ayat-ayat ditulis dalam batasan-batasan strofa yang telah ditetapkan dan apakah panjang strofa mendapat perhatian? Berkaitan dengan seni puisi tentunya kepekaan dan penghayatan kesusastraan lebih bernilai dari penyusunan defenisi, maka cinta dan

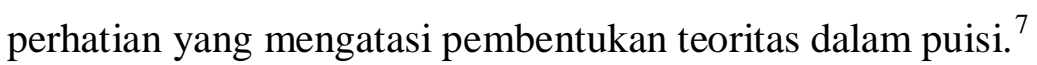

Fokkelman mengatakan selama ini puisi sudah mewarnai literatur sastra Alkitab, yaitu dalam seluruh kitab Mazmur, Amsal, Kidung Agung, Ratapan, Ayub, Kitab Nabi-Nabi. Ada pula puisi yang berkisah tentang sejarah, mulai dari Kejadian sampai pada kitab Raja-Raja (Kejadian 49, Ulangan 31; 32, HakimHakim 5, Keluaran 15, I Samuel 2: 1-10, II Samuel 1: 19-27, II Samuel 22). Dalam Alkitab Ibrani, prosa diceritakan secara berurutan sedangkan puisi dicetak dalam bentuk sajak sehingga baris-barisnya tidak terisi penuh. ${ }^{8}$ Berdasarkan ungkapan definisi baru yang lengkap mengenai puisi oleh Fokkelman bahwa puisi berdasarkan Alkitab hendak menyusun sebuah ayat yang mungkin mempunyai dua atau tiga bagian lebih dari $90 \%$ untuk mengisi ruang dan tempat tinggal dalam lingkup budayanya sendiri serta aturan sastra yang berlaku. Dengan demikian dapat dipahami pembaca, penulis puisi yang menggunakan pararelisme 
untuk menyeimbangkan bagian-bagian ayatnya dan untuk menguasai materinya. Ia menciptakan equivalensi dengan memasukkan unsur kesejajaran dalam bagianbagiannya. $^{9}$

Pada tahap awal penyusunan yang dilakukan oleh penulis puisi adalah beralih pada susunan kalimat untuk menjelaskan dengan istilah sintaksis dan bagaimana penulis puisi dapat memilih salah satu dari keempat kemungkinan sebagai berikut. ${ }^{10}$ Pertama, suatu keputusan yang menarik dan sudah semestinya untuk mengisi baris (pola) dengan satu kalimat pendek terdiri dari dua sampai lima kata. Hal ini mudah karena bahasa Ibrani klasik dapat mengungkapkan dengan padat. Dengan demikan, kalimat sederhana (Inggris: clause) sama dengan kola. Jika penulis puisi yang mengulangi tindakan itu melalui bunyi, bentuk tata bahasa atau makna kata menciptakan suatu ikatan yang kelihatan, maka terciptalah sebuah ayat yang lengkap, sebuah bikola. Ayat ini dengan kesejajaran bagian-bagian untuk kesekian kalinya merupakan perwujudan dari sesuatu yang bernilai sama. Situasi ini sering dijumpai dalam Alkitab. ${ }^{11}$ Kedua, penulis puisi juga bisa memutuskan untuk mengucapkan atau menuliskan sebuah kalimat majemuk yaitu sentence. Hal Ini merupakan susunan sintaksis yang terdiri dari sebuah kalimat induk dan satu anak kalimat atau lebih, tetapi jika ingin ditetapkan pada kalimat majemuk maka dapat dikembangkan menjadi satu pola. Hal demikian beberapa kali masih dapat jumpai seringkali dilakukan oleh penulis puisi untuk memberi sebuah kola dalam setiap bagian kalimat majemuk. Istilah clause juga digunakan bagi "induk kalimat" dan "anak kalimat" dalam sebuah kalimat penuh. Pilihan yang kedua, juga merupakan penerapan dari persamaan satu clause sama dengan satu pola. Berikut dua contoh ayat dalam kitab Mazmur: ${ }^{12}$

Berbahagialah orang (induk kalimat) yang tidak berjalan menurut jalan orang fasik (anak kalimat), yang tidak berdiri di jalan orang berdosa (anak kalimat), dan tidak duduk dalam kumpulan pencemoh (anak kalimat), tetapi kesukaannya ialah Taurat Tuhan (anak kalimat), dan merenungkan Taurat itu siang dan malam (anak kalimat).

Ketiga, penulis puisi bisa saja mengucapkan sebuah kalimat yang panjang, tetapi tidak majemuk hingga melampaui batas satu-satunya kola. Biasanya penulis puisi membagi bahannya menjadi sedemikian rupa, sehingga inti kalimatnya 
terdapat dalam satu kola, sementara keterangan lebih lanjut ditetapkan dalam kola yang lain. Hal demikian terjadi dalam trikola Mazmur $2:^{13}$

Ayat 2 a. raja-raja dunia bersiap-siap (induk kalimat sekaligus inti

kalimat b). dan para pembesar bermufakat bersama-sama (induk kalimat), melawan Tuhan dan yang diurapinya (keterangan bagi kalimat a dan b).

Kempat kedaulatan pola tak tersentuh meskipun sebanyak dua kali penulis puisi memasukan sebuah ucapan, maka baris puisi terdiri dari dua kalimat. Keadaan yang demikian sering terjadi. Sebagai contoh, kita lihat kola B dari mazmur pasal 2:7, ayat dengan tiga bagian: ${ }^{14}$

Aku mau menceritakan tentang keputusan Tuhan Ia berkata kepada ku: anak ku engkau Engkau telah ku peranakan hari ini

Fokkelman telah mampu menganalisis banyaknya puisi dalam Alkitab Ibrani klasik menjadi dasar untuk memaknai nilai-nilai sastra. Peletakan empat bagian ini menjadi penting sebab kita harus memahami fungsi kola (majemuk sintaksis) dalam puisi untuk memberikan makna anak kalimat dan induk kalimat puisi. Ada banyak ayat-ayat yang digunakan oleh Fokkelman tetapi empat cara untuk mendudukan kerangka puisi.

\section{* Media, Penginjilan, dan Semiotik}

Menjadi gereja yang tugas pokoknya memberitakan Injil maka gereja memerlukan "media penginjilan" (maksudnya wujud dari Alkitab). Media penginjilan adalah alat untuk menyampaikan informasi Injil kepada pendengar (umat), contohnya media televisi yang menyebarkan informasi secara universal bagi masyarakat atau radio dan lainnya. Media Penginjilan selayaknya seperti media komunikasi lainnya tetapi tidak segampang itu menyamakan media penginjilan dan media komunikasi. Namun, sistem kerja media penginjilan dapat mengambil sebagian sistem komunikatif dari media komunikasi lain. Media komunikasi bukanlah suatu subjek dari pengertian akademik yang normal. Melainkan merupakan area studi multisipliner sebab di sana informasi bersifat beragam. Media merupakan alat komunikasi yang melihat hubungan komunikan, transmisi, transmiter. Terkait dengan bagaimana pengirim dan penerima mengkonstruksi pesan dalam istilah semiotik (encode) dan menerjemahkan (decode), dan bagaimana transmiter menggunakan saluran media dengan benar sebagai proses yang efesien dan akurasi. Dimana hubungan atau saling 
mempengaruhi orang lain atau state of mind adalah demi mengetahui kegagalan dan keberhasilan dalam pertukaran makna secara komukatif. ${ }^{15}$ Media melihat bagaimana teks berinteraksi dengan penerima teks (komunikan). Penginteraksi media mengarah kepada penemuan nilai, sama halnya dalam mempelajari semiotik (ilmu tentang tanda). Selanjutnya, seseorang menafsirkan teks dengan caranya sendiri dari keberadaan lingkungannya (dirinya) untuk mengungkapkan "nilai dalam tanda". ${ }^{16}$ Fikse mengemukakan tentang analisis semiotik yang mampu memahami produk teks sebagai bentuk efektifitas media dalam tindakannya (reading behing the lines). ${ }^{17}$

Media penginjilan merupakan bentuk dari bahan-bahan Injil yang mengorganisir sekumpulan nilai dalam percakapan mengenai makna keselamatan dari tindakan bermisi oleh gereja sehubungan dengan keadilan sosial dan penumbuhan iman membawah kita ke dalam refleksi tentang hakekat penginjilan. Konsep menginjili sudah hadir lebih lama dari kata misi (dalam Perjanjian Baru adalah euangelizein atau euangelizesthai atau euangelion). Kalau terjemahanterjemahan dalam bahasa Inggris yaitu euangelion biasanya diterjemahkan Injil dan euangelizesthai atau euangelizein biasanya diterjemahkan memberitakan Injil. ${ }^{18}$ Penginjilan adalah bagian yang terintegral dari misi, memang berbeda tetapi sekali-kali penginjilan itu tidak bisa dilepaskan dari bergereja. Penginjilan dapat dipandang sebagai hakiki keseluruhan kegiatan bergereja. Stoot dan Lausanne Covenant mengemukakan bahwa penginjilan adalah satu dari dua bagian atau komponen misi (yang lainnya dalah pelayanan sosial). Penginjilan sekali-kali tidak boleh dibiarkan hidup sendiri, terpisah dari bagian lain kehidupan gereja dan pelayanannya. ${ }^{19}$ Penginjilan (evangelism) adalah tindakan pemeliharan hidup yang berkelimpahan demi merawat dan menyembuhkan. Penginjilan melibatkan kesaksian tentang karya Tuhan yang telah dilakukan-Nya bahwa Allah turut bekerja di dalam alam semesta melalui selang waktu penciptaan. Dengan demikian penginjilan adalah proses menyampaikan kabar sukacita dan bukan proses menghakimi manusia. Penginjilan menawarkan keselamatan, kedamaian sebagai sebuah karunia yang penuh sukacita. Kegiatan ini menempuh perluasan gereja untuk membangkitkan nilai-nilai hidup dalam relasinya dengan kosmik. Sekali-kali penginjilan tidak dapat dipisahkan dari praktek keadilan, perdamaian. 
Penginjilan bukan upaya merekrut anggota tapi menciptakan kesadaran dan pembebasan bagi manusia yang terdiskriminasi.

Upaya penginjilan memperlihatkan bahwa Tuhan telah bekerja bersama dengan manusia untuk memenuhi kebutuhan jasmaniah dan rohanniah dalam tugas diakonia gereja. ${ }^{20}$ Penginjilan membuat gereja bertambah dewasa untuk memberikan pengetahuan, pemahaman tentang Kristus dan ajaran-Nya. Gereja membutuhkan kekuatan Allah yang dapat mendorong gereja untuk berlaku sesuai kehidupan Kristus. Penginjilan tidak lalu statis pada dirinya, ia harus keluar demi membuat gereja bergerak menentukan hakekat dirinya bahwa Kristus senantiasa mengasihi dunia selain gereja sendiri. ${ }^{21}$ Tujuan pemberitaan Injil Yesus Kristus selamanya adalah tugas gereja yang terus diperbaharui. ${ }^{22}$ Penginjilan atau pemberitaan Injil tetap mencari jalan dan meraba-raba hidup untuk menerobos, sekaligus membangun manusia dan imannya kepada Tuhan. ${ }^{23}$ Memahami Injil berdasarkan satu media penginjilan bukanlah hal yang mudah.

Selebihnya semiotik atau semiosis harus menjadi dasar untuk hermeneutik terhadap sintaksis-sintaksis tata bahasa. Analisis Semiotik bertujuan memahami makna, mengungkapkan dan memberikan nilai-nilai (pertanda) dari teks (tanda, penanda) kepada setiap pembaca dan pendengar. Semiotik mempunyai sistem tanda yang ada di dalam medium bahasa. Analisis semiotik akan menunjukan simbol kata yang memiliki arti atau lebih dengan penentuan konvensi penulis dan partisipan. Pembedahan semiotik digunakan untuk melihat, membuka sebutan tanda-tanda (metaphor), lambang dan sebagainya yang disebut semiotika atau semiologi. Menggambarkan hubungan alamiah antara tanda dan petanda. Menujukkan sebab-akibat seperti asap itu menandai api, suara itu menandai orang. ${ }^{24}$ Begitupun simbol kausal alamiah antara penanda dan petandanya yang bersifat arbiter (semau-maunya), berdasarkan konvesi masyarakat. Yaitu maknanya lambang adalah bahasa yang diciptakan, makna simbol ditentukan oleh masing-masing orang dan tersepakati bersama (consensus).

Semiotik digagas pertama kali di bidang pengetahuan medis oleh Henry Stubbes $^{25}$ untuk mempelajari berbagai gejala penyakit. Kemudian diadobsi oleh Charles Sanders Peirce untuk mengamati berbagai fenomena berbahasa dalam masyarakat dan kebudayaan yang ia katagorikan sebagai filsafat pragmatis yang melampaui struktur-sturktur sintaksis dan gramatika. Namun, Algirdas Julien 
Greimas mengembangkannya lebih ke geneneratif semiotis. Ia menggeser fokus studi tentang tanda ke sebuah sistem signification (pemaknaan), sedangkan Ferdinan De Saussure menggunakan istilah semiologi sebagai ilmu. Jika kata pada dirinya (signifier), tidak bermakna kecuali diberi makna lewat proses semiosis oleh (otak) tentunya manusia menghubungkan signifier (kata) dengan signified (benda). Gagasan-gagasan awal semiotika, kemudian dikembangkan orang dalam berbagai bidang (von uexkull di bidang biologi; voloshinov di bidang filsafat social dan bahasa; hjelmslev teori formalism). Tetapi yang paling pengaruh dewasa ini adalah teori semiotik yang dikembangkan Umberto tentang empat modes of sign reproduction: recogniton, ostension, replica and inention.

Kemudian berkembanglah Sosio-semiotik pertama kali yang digagas oleh Michael A.K. Halliday ${ }^{26}$ lewat bukunya Languege As Social Semiotik yang menentang gagasan tradisional (cara-cara yang diadobsi lembaga-lembaga bahasa Indonesia soal teori bahasa baku) tentang pemisahan antara bahasa dan masyarakat (gagasan Halliday tentang purposes/areas or metafunction). Semiotik mengfokuskan dirinya dengan teks. Pembaca dan penerima sama-sama mengalami kondisi kreatif melihat pada pengalaman, sikap emosinal teks-tur. Seperti dikemukaan oleh Peire (1931-1956) dan Ogde Richard (1923) yang menggambarkan simbolik tanda dan objek interpretasi.

Semiotik menggarap teks pada suatu konstruksi tanda. Pengirim mendefinisikan dalam bentuk transmiter pesan sesuai arti pentingnya. Penekanan bergeser pada teks dan bagaimana teks "dibaca" dan membaca adalah proses menemukan makna yang terjadi ketika mendengar, berinteraksi dengan orang lain terhadap kode dan tanda. ${ }^{27}$ Semiotik memandang media sebagai pembangkit nilainilai pesan, baik penyampaiannya atau penerimanya (encoder atau decoder) karena makna bukan konsep yang mutlak dari statis yang ditemukan dalam kemasan teks. Pemaknaan merupakan proses aktif, menciptakan, membangkitkan, menegosiasikan arti. Istilahnya menuju kesana dan kemari (to-and-for), memberi dan menerima (give-and-take). Di antara manusia dan pesan makna merupakan hasil interaksi dinamis antara tanda, intepretasi dan objek. Bahkan makna dapat berubah dari proses "pemaknaan".

Demikian T. S. Eliot via Sansom menyatakan, puisi adalah karya seni mempunyai makna (arti) dan meningkatkan fungsi estetik fenomena atau unsur- 
unsur karya sastra. Dihubungkan dengan semiotik dan fungsi estetik maka terarah pada bunyi dan kata. Bunyi merupakan efoni dan kakofoni; kombinasi vokal dan konsonan tertentu; aliterasi dan asonansi. Simbol bunyi yaitu anomatope, kiasan suara, lambang rasa dan terdapat dalam sajak pada awal, tengah, dan akhir. Termasuk pembicara yang adalah irama yaitu metrum dan ritme. Kata meliputi pembicara, kosa kata, unsur atau aspek ketatabahasaan. Masalah denotatif dan konotatif, pilihan kata (diksi), bahasa kiasan; sarana retorika dan gaya kalimat, serta gaya puisi. ${ }^{28}$ Prinsipnya semiotika mengenai tanda dengan cara bekerjanya, dinamakan semiotik atau semiologi. Di mana pembaca dan penerima memainkan peran yang lebih efektif. Pembacaan seharusnya ditentukan oleh kultural pembacanya agar menciptakan makna teks dengan membawa pengalaman, sikap, dan emosinya terhadap teks tersebut.

\section{METODE PENILITIAN}

Penulisan masalah ini menggunakan metode penelitian kualitatif. Lokasi penelitian di sekitar Kota Ambon. Penelitian dilakukan selama satu bulan. Sumber data utama (primer) adalah puisi yang akan diklasifikasi, sedangkan hasil-hasil wawancara dan buku-buku yang berhubungan dengan penelitian sebagai sumber sekunder. Selanjutnya penelitian ini menggunakan teknik analisis data dengan pendekatan analisis deskriptif terhadap satuan data.

\section{HASIL DAN PEMBAHASAN}

\section{a. Semiotik Puisi Duang e}

Puisi Dueng e mempunyai gambaran pengalaman iman dalam jiwa penyair. Karya Duang e memiliki kombinasi-kombinasi bunyi yang merdu atau ephony sastra. Orkestrasi bunyi tersebut dapat menggambarkan perasaan mesra, keagungan, kasih sayang dan cinta sang penyair kepada Tuhan. Kemerduan puisi Duang $e$, disebabkan oleh perasaan kontempolasi dan imajinasi yang tetap hidup pada konteks kosmologi Kei yang diharmonikan berdasarkan pilihan kata. Puisi Duang $e$ selamanya menimbulkan setiap artikulasi menjadi tanda dan makna. Ada pun simbolik gairah, gembira, perasaan marah, dan keheranan, yang membuat penentuan intiusional puisi menjadi satu pemikiran yang utuh dan menggambarkan relasi "vertikal dan horizontal". 
Di altar ini

Kau beri aku warna-warni

Pasir seumpama salju putih

Lembayung jingga merah

Pulau-pulau kecil begitu biru

Dikungkung rumput-rumput hijau

Di tepi altar ini

Sekarang baru aku tahu

Ibuku adalah lautan itu

Ombak adalah gairah

Angin adalah orkes

Arus adalah lirik

Duang e

Minta ampun

Sekarang baru aku mengerti

Butir-butir surgawi

Pada butir-butir pasir

Pada kemilau ganggang laut

Di sini negeri matahari

Dia selalu turun mandi

Tiap kali cahayanya begitu gilang

Aku terjatuh seperti Saulus

Pada jantungku yang gementar

Kau adalah rahim

Ngurbloat, Agustus 2010

Berdasarkan konsep sintaksis majemuk yang terdiri dari anak kalimat dan induk kalimat oleh Fokkelman, maka dapat diperlihatkan kerangka puisi Duang $e$ sebagaimana mestinya. Bait pertama terdiri dari satu induk kalimat, satu anak kalimat dari induk kalimat pertama dan empat anak kalimat biasa (kalimat keterangan). Sama halnya dengan bait pertama, demikian juga bait kedua. Di dalam bait ketiga teridiri dari satu induk kalimat, dua anak kalimat dari induk 
kalimat dan tiga anak kalimat biasa (kalimat keterangan). Bait keempat, induk kalimat terdapat pada bagian baris ke enam, sedangkan baris pertama sampai kelima adalah anak kalimat yang menjadi keterangan induk kalimat. Kerangka inilah yang mampu memberikan kesinambungan makna puisi Duang e.

Puisi Duang e, terdiri dari empat bait dan masing-masing bait terdiri dari enam baris. Penyair sangat sistematis mengungkapkan apa yang ia rasakan berdasarkan bait per bait puisi sehingga tidak dapat dipisahkannya bait puisi sendiri-sendiri. Puisi Duang e mempunyai irama yang liris, memiliki kepadatan rasa di setiap ekspresif bahasa berdasarkan struktur sintaksis normatif. Pemilihan kata serta penyusunan kalimat sastra membuat puisi ini benar-benar hidup. Tergambar jelas mengenai citra pergerakan ungkapan-ungkapan lirik yang mengalir menjadi keutuhan, berkesinambungan. Baris pertama dalam setiap bait adalah sampiran dan baris kedua sampai keenam adalah isi puisi.

Puisi Duang e adalah gabungan satu kata dan satu huruf yang menunjukkan makna seruan. Arti Duang yaitu Tuhan yang berasal dari kata Duad. Duang hanya digunakan oleh masyarakat Kei untuk maksud "menyapa Tuhan" (realitas tertinggi/ realitas teologis). Ungkapan Duang dipakai dalam upacara-upacara adat atau kebiasaan "masyarakat adat" sebagai ungkapan iman.

Huruf $e$ merupakan penegasan terhadap kata Duang seperti Tuhan e, Mama e, Bapa e, Kaka e, Adi e, Sudara e, Gandong e. Duang e bukanlah satu makna bahwa penyair sedang sakit apabila kita samakan dengan Ado e. Bahkan menandakan seseorang sedang membutuhkan pertolongan dari orang lain terhadap satu kesakitan yang sempat dia hadapi. Penambahan huruf $e$ menggambarkan Duang e merupakan seruan keagungan kepada Tuhan dengan "penuh mesra dan lembut". Seruan penyair yang dikeluarkan serupa keharuan jiwa bahwa Duang atau Tuhan adalah unsur benar-benar agung. Ungkapan Duang e membuat penyair benar-benar memiliki relasi kepasraan dalam cintanya kepada Tuhan dan alam semesta.

Kiasan Duang selayaknya menjadi metafora-metafora hidup yang terpersonifikasi membentuk benda-benda alam. Personifikasi yang tersirat dipergunakan penyair sebagai kebesaran makna Tuhan. Bahkan personifikasi membuat keutuhan internalisasi dari realitas konkritsitas menuju realitas Tuhan yang sangat baik dan agung di alam Kei. Demikian judul Duang $e$ menjadi acuan 
menyeluruh bagi isi puisi Duang e yang memberi penekanan kepada pengakuan manusia rohani yang adalah mahkluk rohani dalam keberadaan dirinya sebagai manusia berbudaya yang adalah mahkluk berbudaya.”

\section{Bait Pertama:}

\section{Di altar ini}

Kau beri aku warna-warni

Pasir seumpama salju putih

Lembayung jingga merah

Pulau-pulau kecil begitu biru

Dikungkung rumput-rumput hijau

Di altar ini (induk kalimat), adalah satu pengakuan latar tempat asal penyair. Penyair berasal dari tempat atau konteks pulau Tenggara, Kepulauan Kei yang berlimpah kekayaan alam khususnya di lautan (fokus puisi). Betapa Di altar ini adalah di tanah Kei tempat penyair bertumbuh. Tanah Kei merupakan altar suci tempat manusia Kei bergumul, menyatu dengan alam dan mengalami Tuhannya. Di setiap "altar" pastilah Tuhan tetap tinggal dan berkarya dalam kesakralan-Nya. Altar memperlihatkan satu kekuatan Ilahi yang selamanya diakui bahwa Tuhan ada ditengah-tengah ciptaan-Nya (seperti makna mimbar). Sehingga altar dijadikan tempat pergumulan yang dibawakan khusus oleh setiap hamba Tuhan (atas mimbar atau bawah mimbar). Nilai Injil yang terkandung dari baris ini adalah kekudusan, pengharapan, kedekatan, kekerabatan, dan perjumpaan.

Kau beri aku warna-warni (anak kalimat dari induk kalimat), sebab Kau adalah Duang atau Tuhan pencipta segala alam semesta dengan karya yang penuh keberagaman. Kau beri aku, sebab $a k u$ adalah penyair yang tetap memiliki, menghargai dan mencintai tanah Kei. Kau beri aku sebab aku adalah manusiamanusia Kei. Kau beri aku warna-warni sebab bukan lagi $a k u$ dan manusiamanusia Kei tetapi kami yang adalah keutuhan pluralitas yang ada. Warna-warni menjadi khasa keragaman di tanah Kei. Hidup dalam perbedaan-perbedaan ras, agama, etnis, budaya yang unik tetapi perbedaan itu membuat estetika hidup kami terpelihara. Secara tegas penyair ingin menyampaikan bahwa perbedaan adalah anugerah pemberian Tuhan dan perbedaan patut dihormati. Warna-warni sejelasnya akan penyair dalam baris-baris berikut. Nilai Injil yang ditemukan dalam baris ini adalah keberagaman atau kemajemukan, dan keindahan. 
Pasir seumpama salju putih (anak kalimat biasa), merupakan metafor penyair yang menggabungkan dua unsur alam. Penyair mulai merasa nikmat dengan satu unsur alam yaitu Pasir putih di pesisir pantai Kei sehingga diumpakan seperti salju putih. Pasir adalah unsur yang halus, jumlahnya banyak secara bentuk dan secara jenis warna pasir tidak berwarna putih, warnanya beragam. Apa pun itu, pasir bersifat anasir yang kasar dan keras sebab dari pasirlah terbentuklah batu. Untuk membuat pasir tetap halus dan indah maka penyair mencuri sifat putih, lembut, lembab, dingin dari unsur salju sebab suasana lembab itulah membuat setiap orang merasakan kenyamanan, keindahan dan keagungan. Pasir telah dipertegas menjadi bentuk salju putih agar kesucian tetap mewarnai unsur alam tanah Kei. Nilai Injil yang didapat dalam baris ini adalah ketulusan, penyatuan, pembaharuan, dan kesejahteraan.

Lembayung jingga merah (anak kalimat biasa) adalah tumbuhan melilit yang bunganya berwarna ungu. Menggambarkan segala yang tumbuh di tanah Kei adalah begitu menawan eksotik. Jingga merah, disitulah penyair menyimpan atau membalikan kalimat merah jingga. Warna merah jingga menujukan kepada sifat molek, indah, bagus, hidup, cinta, atau seperti gadis yang merah wajahnya dan cantik. Mungkin saat itu, keindahan tumbuhan-tumbuhan di kepulauan Kei membuat penyair merasa terharu dan ia jatuh cinta kepadanya. Betapa Lembanyung telah menyatu dengan merah jingga hingga menciptakan pesona keindahan alam. Nilaii Injil yang didapat adalah kekagungan, kemuliaan, dan keberanian.

Pulau-pulau kecil begitu biru (anak kalimat biasa), adalah bentuk hasil karya Tuhan di tanah Kei. Kei adalah negeri kepulauan yang terdiri dari pulaupulau kecil (karakteristik kemalukuan). Pulau merupakan tempat berpijak atau berdiam dan setiap mahkluk hidup dapat bertumbuh dengan kesederhanaan dan keluasannya. Mengapa pulau-pulau kecil begitu biru sebab mereka (pulau Kei) terus ada menjaga dan tetap setia menjadi rumah tempat asal anak-anak Kei betumbuh. Pulau-pulau kecil sebisanya akan memberikan penerangan atau "sombar" sebagai satu kekuatan, semangat hidup. Nilai Injil yang di dapat dalam baris ini adalah pengharapan, penghormatan dan kesejahteraan. 
Dikungkung rumput-rumput hijau (anak kalimat biasa), berpengertian pada "pengikat atau mengikat" sesuatu dan rumput-rumput menuju pada pengulangan banyak tumbuhan yang terus-menerus bertumbuh dengan ruas-ruasnya memenuhi "pulau-puau kecil begitu biru". Hijau adalah penegasan kepada warna rumput yang mempunyai gabungan warna biru dan kuning. Warna hijau membawakan kita kepada kesejukan suatu realita karya Tuhan jika kita memandanginya. Nilai Injil yang didapat dalam baris ini adalah perlindungan, penyatuan, naungan.

Bait pertama tergambar keutuhan rima dan makna dalam baris-baris syair. Anak-anak kalimat biasa telah menjelaskan tuntas induk kalimat. Penyair sangat bergairah untuk menyerukan keindahan tanah Kei. Altar sebagai penegasan generalisasi konteks penyair. Konteks itu mewarna-warnai satuan baris-baris lanjutan yaitu warna putih, jingga merah, biru, hijau dengan mewujudkan estetika Allah. Ia adalah pencipta alam semesta (aku “manusia”, pasir, salju, lembayung, pulau-pulau, rumput-rumput) yang di satukan atau dikungkung dalam lestarinya keragamaan alam ciptaan sebagai sumber segala kehidupan.

\section{Bait Kedua:}

Di tepi altar ini

Sekarang baru aku tahu

Ibuku adalah lautan itu

Ombak adalah gairah

Angin adalah orkes

Arus adalah lirik

Baris pertama "Di tepi altar ini (induk kalimat)" adalah pergeseran baris pertama (induk kalimat) dalam bait pertama yaitu di latar ini. Penyair menambahkannya menjadi Di tepi altar ini. Di tepi, memberikan nuansa kesadaran keberadaan diri penyair/ manusia sebagai seorang hamba Tuhan. Manusia bukan hanya dapat menarik makna dari samping altar, tetapi ia merasakan atau menikmati segala yang ada. Tidaklah manusia harus berada pada kesombongan yang menjadikan dirinya sebagai pusat kekuasaan alam, pencipta eksistensi altar tanah Kei. Nilai Injil yang ditemukan dalam baris ini adalah kesadaran dan kerendahan diri. 
Sekarang baru aku tahu adalah ungkapan kesadaran akan segala keistimewaan alam. Sekarang baru aku tahu bukan kepura-puraan penyair atau selama ini penyair tidak tahu tentang apa yang ada. Sekarang menujuk pada latar pengakuan hakekat kebanggaan terhadap sebagain unsur alam yang dilihat pada kesempatan syair puisi Duang e ditulis. Baru adalah tanda perkenalan bahwa $a k u$ diri panyair benar-benar ingin menyatakan apa yang aku tahu. Tahu adalah makna mengetahui dari hasil penglihatan, hasil pengertian. Hasil pengetahuan dijelaskan secara sastrawi pada baris keempat sampai keenam yang membentuk sebuah defenisi pengetahuan. Nilai Injil yang di dapat dalam baris ini adalah kesadaran dan ketidaksadaraan.

Ibuku adalah lautan itu merupakan metafora tempat setiap manusia lahir dari rahimnya Ibu. Begitu lama lautan Kei telah memupukan kekayaan Maluku dan telah menjadi sumber Rahim bagi orang-orang Kei selain hasil-hasil hutan. $I b u k u$, menujuk kepada $i b u$ penyair tetapi tidak segampang itu ibuku adalah ibu penyair. Ibuku merupakan perwakilan metafora terhadap laut. Gambaran ibu yang adalah kaum wanita, merupakan sosok yang sifatnya lembut, bersahaja, sabar, tegar, dan kuat memelihara anak-anaknya. Adalah mempertegas bahwa kebenaran lautan Kei telah menjadi $I b u$ yang selamanya menebarkan luas kasih sayang dengan setia seperti warna di dalam kebiruan. Nilai Injil yang di dapat dalam baris ini adalah ketulusan, cinta, tidakterbatas, tanggungjawab, keteladanan, pendidikan, ketaatan.

Ombak adalah gairah merupakan ungkapan gerakan yang dinamis, tidak statis, ia tetap bergulung-gulung dan pecah berbuih-buih putih. Ombak adalah bagian dari lutan. Ia selamanya memiliki nada-nada yang tidak pernah mati dan terus diperdengarkannya. Ombak terus bergerak bergulung naik turunnya sehingga "penyair menyimpulkan telah menjadi satu gairah. Gairah adalah rasa ingin yang berlebih, keberanian, gembira penuh emosional. Ternyata ombak telah membuat gairah lautan untuk tetap menghidupkan alam dan manusia Kei hingga kehidupan menjadi kekuatan yang tak putus-putusnya. Nilai Injil yang didapat adalah spritualitas.

Angin adalah orkes merupakan kemerduan, gerakan yang lembut dan berirama, suara indah dan menyejukan. Angin tetap menjadi bagain dari "lautan", ia dapat menciptakan "gelombang" semaunya dan sebesarnya. Orkes merupakan 
perlengkapan musickal yang pastinya akan menghasilkan kemerduan. Angin terbentuk dari pergerakan sistim udara yang bertekanan secara norma ekologis. Bisa juga bersifat amarah (membentuk badai), kelembutan, kenyamanan. Angin memiliki kesamaan dengan orkes membentuk kiasan bunyi dan lambang rasa yang memiliki arti, romantik dan indah. Nilai Injil yang di dapat adalah kesejukan, spritualitas, kenikmatan, kegirangan, kebebasan.

Arus adalah lirik merupakan aliran atau siklus kehidupan yang terikat pada satu keutuhan menuju kepada kesempurnaan yaitu permulaan akan sesuatu yang menarik dan terjadi sebagai keteraturan, kepadatan berisi rasa, perasaan, ungkapan, cerahan. Arus muncul dari pergerakan angin, ia akan mengalir, bergerak dengan deras dan penuh tenaga alami. Adalah menyatakan penyelarasan atau penegasan secara sama dengan makna lirik yang sangat kuat dan penuh keutuhan makna sastra. Lirik dapat mempengaruhi situasi hidup seorang begitu pula arus, ia mendasar dari satu gelombang. Nilai Injil yang di dapat dalam baris ini adalah penuntun atau pedoman, tatanan, spritualitas.

Hubungan bait pertama dan kedua memperlihatkan situasi berbeda yang mempunyai makna lain. Menjelaskan tentang kesadaran terhadap diri sendiri dan manusia. Menyatakan persamaan dan keindahan, pemeliharaan serta tujuan hidup. Ada altar yang diulang dari bait pertama dan menambah kata tepi di bait kedua. Penyair hanya mengkemas satu unsur alam yaitu laut dan membagi-baginya ke dalam bentuk kesatuan metafora ibu, lautan, ombak, gairah, angin, okres, arus, lirik berupa keluasan yang menggambarkan realitas kekuatan, pergerakan dan kekuasaan Allah atas karyanya yang indah. Perpaduan ibu dan lautan, ombak dan gairah, angin dan oreks, arus dan lirik bertujuan menembas ruang-ruang metafora.

\section{Bait Ketiga:}

Duang e

Minta ampun

Sekarang baru aku mengerti

Butir-butir surgawi

Pada butir-butir pasir

Pada kemilau ganggang laut 
Duang $e$, merupakan seruan permohonan kepada Tuhan (Tuhan e...). Bersifat sapaan pada kedekatan dan keakraban. Duang diyakini masyarakat Kei sebagai pencipta manusia dan pemeliharaan alam semesta. $e$ huruf yang dipakai orang Maluku (aksentuasi) dalam setiap lagu atau ungkapan sosial untuk menggambarkan penekanan kedekatan, keakraban, atau ratapan kepada sesuatu yang keberadaannya jauh atau sangat tersayang. Nilai Injil yang didapat dalam baris ini adalah kemuliaan, kuasa, penyelamatan.

Minta ampun merupakan penyerahan diri, pemulihan diri demi mengarahkan konsep pengakuan (dosa) untuk Tuhan (Tuhan e minta ampun). Minta ampun mengarah pada pembentukan karakter perubahan dan sikap diri dihadapan Duang. "minta" merupakan totalitas keinginan untuk mendapatkan pengampunan dari semua kesalahan yang pernah penyair atau manusia Kei lakukan dengan hubungannya pada pemeliharaan alam semesta. Nilai Injil yang didapat dalam baris ini adalah pertobatan, kesadaran, pengampunan. Pertolongan, harapan.

Sekarang baru aku mengerti, adalah latar pengakuan kesadaran pengetahuan terhadap sesuatu yang tercipta. Sekarang baru aku mengerti mempertajam pengakuan sekarang baru aku tahu dalam bait kedua baris kedua. Kata tahu, digantikan dengan kata mengerti, berarti penyair bukan sebatas mengetahui realitas empirik degan rasa indra, tetapi penyair telah melampaui pengetahan menjadi satu perasaan jiwa (pengakuan iman). $A k u$ adalah diri panyair bahkan mewakili semua manusia, yang terus mangalami, "mengerti", memahami, mendalami, realitas penciptaan. Kerangka pengertian itu, penyair kembangkan dalam metafora-metafora di baris-baris selanjutnya. Nilai Injil yang didapat dalam baris ini adalah keimanan, kesadaran.

Butir-butir surgawi merupakan isi pemakanaan penyair yang paling intuisional. Butir-butir surgawi adalah bagian-bagain kecil yang menjadi keseluruan dan keluasan. Penyair memang teratur memberikan penegasan bahwa sebenarnya surgawi yang jauh, bersifat ketenangan, harmonis, kekal abadi. Surgawi semstinya ada di dunia kongkrit. Manusia harus menunjukan suasana surgawi sebagi sistim hidup. nilai-nilai Injil yang di dapat dalam baris ini adalah keilahian, kedamaian. 
Pada butir-butir pasir, merupakan penegasan akan butir-butir surgawi (pembalikan tempat). Butir-butir pasir yang terlihat merupakan transformasi butir-butir surgawi atau keabstrakan yang terlihat. Penyair menempatkan surga pada butir-bitir pasir sebab pasir putih panjang di tanah Kei telah menjadi kebanggaan semua manusia Maluku. Pasir adalah karya penciptaan yang terus ada dan harus dipelihara. Ciri butiran pasir di Kei, membenarkan bentuk tatanan surgawi bahwa surga adalah sesuatu yang nyata dengan sifat-sifatnya seperti butir pasir. Seperti makna pasir dalam penjelasana di bait pertama baris ketiga begitulah realitas surga. Nilai Injil yang didapat dalam baris ini adalah kelahiran, persamaan, dasar.

Pada kemilau ganggang laut merupakan penegasan butir-butir surgawi yang kedua. Surga telah berada menjadi karakteristik kemilau gangang laut. Penyair mengangkat kekayaan eksotik dalam khasana tanah Kei. Pada kemilau yang bercaya, berkilauan, gemerlap, terlalu terang surga membentuk dirinya di sana. Ganggang adalah tumbuhan laut yang warnanya (hijauh, coklat, kemerahmerahan) dan masih banyak bertumbuh di lautan Kei. Ganggang akan berkilau jikalau air laut menyatu dengan cahaya terik matahari. Perpaduan itu membaut sekain keindahan dan gemilangnya tumbuhan ganggang. Nilai Injil yang didapat dalam baris ini adalah keadilan, kesejahteraan, terang.

Bait ketiga memperjelas tentang kesadaran penyair mewakili manusia untuk memohon pengampunan dari Tuhan. Penempatan diri di hadapan realitas.

Tuhan dengan karya Tuhan menjadi nyata. Ada Duang e, minta ampun, sekarang, baru, aku, mengerti, merupakan penyadaran memahami karya Allah yang lebih mendalam. Menegaskan keilahian dalam butir-butir surgawi, dalam butir-butir pasir, pada kemilau ganggang laut. Kekekalan yang tak terhapuskan telah menjadi realita nyata.

\section{Bait Keempat:}

Di sini negeri matahari

Dia selalu turun mandi

Tiap kali cahayanya begitu gilang

Aku terjatuh seperti Saulus

Pada jantungku yang gementar

Kau adalah Rahim 
Di sini negeri matahari (anak kalimat), merupakan pernyataan di tanah "Kei adalah tanah yang menjadi sumber kehidupan". Di sini, penyair mengungkapkan konteksnya tempat berpijak. Negeri matahari mencakupi sifat tanah Kei. Tanah terang, tanah yang kuat menghidupkan manusianya.Tanah Kei adalah karya ciptaan Duang sehingga tanah Kei adalah Tanah Duang. Tuhan tidak lagi jauh di keberadaaan-Nya yang jauh sebab Ia sudah menyatu dan membangun relasi dengan manusia Kei. Nilai Injil yang ditemukan dalam baris ini adalah kehadiran, pemeliharaan, keyakinan, dan keajaiban.

Dia selalu turun mandi (anak kalimat) merupakan penegasan keberadaan matahari yang terbit dan terbenam. Matahari selamanya akan berguna bagi alam ciptaan Tuhan. Dia adalah personalitas Duang atau matahari sendiri. Selalu turun merupakan kreatifitas secara terus menerus. Ia datang, turun bergerak ke bawah,dengan kerendahan. Mandi merujuk kiasan menyesuian dirinya, membersihkan diri, atau mataharilah yang memandikan alam Kei dengan sinarnya (bukan air). Turun mandi merupakan siklus kehidupan membentuk relasi dengan segala ciptaan. Nilai Injil yang didapat dalam baris ini adalah pergerakan, melayani, kerendahan diri, penyelamatan, pelestarian, kemanusiaan.

Tiap kali cahayanya begitu gilang (anak kalimat), penyair memperlihatkan bahwa sinar matahari yang turun memandikan di baris sebelumnya sangatlah terang sebagai simbolisasi kekuasaan Duang. Tuhan e..., Ia begitu elok, tajam kuasa-Nya, terang, amat baik sekali, cemerlang, putih, bersih. Tiap kali kuasa yang diberikan tak pernah putusnya sehingga pemeliharaan-Nya masih terus ada. Nilai Injil yang didapat dalam baris ini adalah keadilan, menghidupkan, menguatkan, menertibkan, mempersatukan, jujur, mensejahterakan.

Aku terjatuh seperti Saulus (anak kalimat), sebagai pengakuan penyair ketika melihat cahaya yang sangat terang. Seperti halnya penyair menempatkan diri bagaikan Paulus yang bertemu Tuhan (berupa sinar) di depan pintu gerbang Damsyik. Aku terjatuh adalah ironis bahwa penyair atas manusia tetaplah seorang hamba di bawah Tuhan. Penyadaran hakekat sebagai manusia yang sekali-kali bertemu dengan Tuhan maka kegilangan cahaya dapat menyengat mata (sama seperti Paulus mengalami kebutaan saat memandang sinar itu). Perjumpaan singkat Paulus dengan Tuhan membuat ia berserah diri untuk berkarya bagi Tuhan. Aku adalah penyair mengungkapkan dirinya sama halnya dengan Paulus 
yang mengakui kemahakuasaan Tuhan. Nilai Injil yang didapat dalam baris ini adalah pertobatan, kesadaran kemanusiaan, penghormatan, kesaksian.

Pada jantungku yang gemetar (anak kalimat), seakan-akan perjumpaan antara penyair atau manusia dan Tuhan membuat "aku" mengalami perombakan fisik dan mental (gemetar, gugup, berdetak). Manusia merasa dirinya sebagai seorang yang tidak berdaya dan tak layak bertemu Tuhan sebab Tuhan teramat bercahaya menggilang. Mengapa pada jantungku? Jantung adalah salah satu pusat anatomi manusia, tanpa jantung manusia tidak bias hidup. Tuhan dengan seriusnya akan melampaui segala pusat hidup manusia dan ia berkuasa atas manusia. Nilai Injil yang didapat dalam baris ini adalah keseimbangan, pemeliharaan, dorongan.

Kau adalah Rahim (induk kalimat), merupakan kesimpulan akhir dari segala bait baris puisi Duang e. Pernyataan penyair telah mengesahkan Duang sebagai Rahim. Rahim adalah segala muasal pembentukan, pemeliharaan, kelahiran, kasih sayang, cinta, awal penciptaan. Duang dikatakan sebagai sumber segala sesuatu di tanah Kei. Terutama keindahan di tanah Kei. Kau itu Duang, sebagai bentuk terikat dengan kata awal maka adalah, merupakan proklamasi keimanan penyair bahwa Duang adalah Rahim. Nilai Injil yang didapat dalam baris ini adalah sumber kehidupan.

Puisi Duang ditulis di Ngurbloat, Agustus 2010. Seperti penjelasan analisis di atas, Duang e berasal dari kata Duad, bahasa Kei yaitu Tuhan. Saulus adalah Saulus dari Tarsus yang menjadi Rasul Paulus, saat ia bertemu Tuhan. Upaya pencarian makna keutuhan pusisi Duang $e$ telah memperlihatkan realitas estetika penciptaan terhadap korespondensi "susunan baris puisi yang tampak di dalam setiap bait, baris dan gaya bahasa".Jika dipandang tentang puisi Duang e maka penyair mengemasnya dalam satu anasir alam yaitu lautan dan memperkaitkannya degan matahari. Lautan telah menjadi keindahan tanah Kei sebegitu lama. Manusia Kei hidup dari kasih sayang Tuhan yang tercurah di lautan tetapi dengan nilai-nilai sastra, penyair telah melampaui tatanan kosmologi orang Kei.

Puisi Duang e berupaya membangun nilai-nilai kehidupan dalam puisi. Entah mengandung nilai agama, estetika, sosial alamiah dan budaya yang dimiliki penyair. Puisi Duang e, memiliki nilai universalis. Ia mewakili segala nilai dan 
menyatukan keberagaman, perbedaan dalam satu paham kekuatan kosmologi dalam karya Tuhan.

Rudy Fofid menjelaskan secara sadar atau pun tidak sadar ia telah menyelipkan nilai-nilai Injil dalam puisi Duang $e$. Injil telah merambat sekian lama membentuk karakternya. Ia bertumbuh melalui tradisi ajaran agama khatolik yang kental. Injil baginya adalah ajaran universal dan membuat ia sendiri terpenjara dalam kebanggaan nilai universalitas Injil itu. Di antaranya nilai-nilai cinta kasih dapat menyentuh keluasan relasi sampai kepada mereka yang tidak mengenal Injil kekristenan. Cinta kasih ditegaskannya, berdasar cara hidup Yesus adalah Tuhan. Ia sekian lamanya menjadi titik sentral ajaran agamanya. Cinta kasih dalam hidup berdasarkan kehidupan Yesus Kristus sama halnya dengan ajaran agama-agama lain yang mengajarkan cinta kasih kepada sesama, cinta kepada alam dan kepada Tuhan. ${ }^{29}$

Pengakuan Rudi Fofid bahwa tidak secara spontan ia dibesarkan di lingkungan gereja (lingkup Khatolit) yang membangun wacana pengakuan imannya. Gereja telah membangun sikap, perasaannya dalam hakekat bergerejanya. Dasar puisi Duang $e$, terbentuk berdasarkan pengaruh lingkup imannya bersama semua imajinasi dan dari pengalaman masa kecil dan latar belakang sosialnya. Ia benarbenar menulis tentang Tuhan tetapi menggunakan bahasa Kei. Puisi Duang e memang memperlihatkan hubungan alam bersama dengan Tuhan yang menjadi dasar tujuan sumber kehidupan bagi manusia.

Rudi fofid sebagai panyair sudah mempercakapkan hakekat konteks dirinya dengan Tuhan. Ia membangun nilai-nilai kehidupan pada setiap bait puisi. Menurutnya pilihan kata dalam puisi Duang $e$ adalah pilihan nilai yang menentukan hubungan iman manusia dengan Tuhan. Puisi Duang e baginya bisa dan bahkan diterima oleh setiap pembaca atau pendengar. Penghayatan dalam penerimaan nilai-nilai sastra puisi Duang $e$ dapat mempengaruhi suasana batin berdasarkan dialektis nilai religi dan latar sosial pembaca sendiri atau pendengar sendiri. Makna Duang e telah mewakili semua realitas Tuhan pada masingmasing kepercayaan pembaca atau pun pendengar untuk menangkap pemahaman kuasa Tuhan. 


\section{b. Puisi Duang $e$ dalam perspektif orang lain.}

Puisi dapat ditafsir sebebasnya oleh setiap orang menurut latar belakang hidupnya tetapi tidak-lalu berdasarkan kemauannya sendiri-sendiri. Sebuah karya puisi jika sudah dibacakan berarti puisi itu sudah menjadi milik semua orang untuk dimaknai berdasarkan aturan normatif sastra dan interpretasi. Tujuannya adalah untuk menemukan pesan dan makna demi menjadi dasar kehidupan agar memberikan nilai-nilai pemeliharaan hidup.

Puisi adalah karya sastra yang memberikan kesadaran mengenai makna hidup. Dalam agama islam ada istilah Halbuminas yaitu sesama manusia, sesama mahkluk ciptaan Tuhan. Puisi Duang e menggambarkan dampak bagi hubungan sama Kristen maupun pembaca dan pendengar Islam dan agama lain. Pembaca mengetahui akan sebutan Duang e sebagai Tuhan e. Bahkan, Puisi Duang $e$ menyentuh berbagai aspek hidup, apalagi ketika puisi itu diartikulasikan oleh pembaca. Pemahaman kata-kata dalam puisi Duang e kekuatan. Misalkan "di altar ini kau beri aku warna-warni”, adalah warna-warni kehidupan, ada senang, sedih, kecewa, gembira, ada perbedaan warna kulit, agama dan ras. Kata "pasir" sebisanya menghangatkan kehidupan, "sekarang aku baru tahu ibu adalah lautan, angin adalah orkes, ombak adalah lirik", adalah pemberian dan keagungan yang diciptakan Tuhan, diperlihatkan kepada setiap manusia.

Manusia diarahkan untuk menghargai, untuk sadar, untuk menyembuhkan dirinya seperti Saulus yang terjatuh dihadapan Tuhan, dan merawat alam semesta. Pengetahuan tentang alam dan iman penyair membuat keindahan hidup itu berlimpah. Ketika pembaca mengingat tentang Tuhannya sama halnya Duang, ia akan berupaya membangun hubungan antara arti dan karya Tuhan yang ia pahami. Puisi Duang e dapat menjadi dakwa bahkan media untuk memberikan sifat-sifat kebaikan (hidup) bagi semua agama.

Puisi Duang e memberikan pembelajaran (lewat makan) untuk memenuhi segala ajaran agama. Kata-kata dalam puisi seakan-akan mempunyai Roh yang memberikan pergerakan bagi pembaca dan pendengar. Hal tersebut memperlihatkan pekerjaan Roh Kudus searah pada jiwa yang mengungkapkan kekuatan iman terhadap apa yang dipercaya. Puisi Duang $e$ telah menjadi cermin estetika yang lembut tanpa menyinggung atau membandingkan apa pun. Puisi Duang $e$ dapat digunakan sebagai media ajaran-ajaran positif. Secara khusus puisi 
Duang $e$ bersifat perenungan diri dan pernyataan diri pribadi, alam, dan orang lain. Kekuatan nilai puisi Duang e, takala menjadi nilai Injili yang terus merekam sistem nilai-nilai. Kekuatan Injil yang dimuat pada puisi Duang e tidaklah berhenti dengan hitungan detik, tetapi terus mengkomunikasikan pesan sastra, tetapi sekaligus menjadi media penyeruan karya Allah. Puisi Duang e telah memunculkan hal-hal mistik religius bahwa keilahian Tuhan telah berada dalam konteks manusia. Keadaan yang ada dalam puisi adalah keadaan yang dialami penyair dan sekaligus di alami orang lain tanpa sadar. Penekanan penyadaran nilai puisi Duang $e$ akan mempertegaskan manusia terhadap kepedulian dan tanggung jawab. Di mana puisi Duang $e$ dapat menghapus asumsi eksklusivitas latar agama, budaya sosial yang berbeda-beda yang adalah tugas bersama. ${ }^{30}$

\section{c. Wujud Puisi sebagai Media Penginjilan.}

Puisi mempunyai sarat makna sehingga jenis genre sastra ini dapat membentuk satu media. Khususnya media penginjilan yang mana puisi sudah mengandung keutuhan nilai-nilai, kebebasan berdasar konsep estetika. Kekuatan media pada perkembangannya menentukan keberhasilan dalam tujuan untuk memberikan tatanan nilai agar tidak terjadi penolakan dan perbantahan. Jika upaya memberikan cinta kasih kepada siapa saja adalah perwujudan nilai Injil maka "puisi, lukisan, patung, cerita, esay telah lama mengungkapkan nilai itu". Puisi dapat diletakan menjadi media sebab mempunyai nilai-nilai Kristiani yang dapat digunakan untuk menginjili manusia. Dalam sifatnya, puisi sangat halus dan lembut. Ada juga kritik yang mendominasi pembebasan dan membangkitkan kesadaran manusia. Kata-kata dalam puisi adalah pesan dan nilai-nilai Injil. Puisi dan Injil sama-sama lahir berdasarkan realitas manusia. Puisi telah menjadi milik semua pembaca dan pendengar, tanpa memandang status dan golongan apa pun. ${ }^{31}$

Rudi Fofid menegaskan betapa banyak orang yang membaca puisinya dan menemukan nilai-nilai Injil sebagai sifat universal. Nilai itu tertuang melalui simbol-simbol yang dapat dimengerti dan dimaknai, atau ditukarkan dengan simbol yang dipahami dan disamakan dengan kepercayaan masing-masing orang. Media penginjilan merupakan ruang yang penuh dengan nilai-nilai Injil. Nilai yang baik tentu diterima semua orang. Puisi lebih menekankan hal baik dengan ide, maksud dan tujuan. Puisi menandakan perubahan hidup yang tidak statis melainkan dinamis. Nilai perubahan membuat setiap orang tidak mungkin 
menentukan hal-hal yang mutlak oleh manusia. Pembentuk nilai-nilai dan katakata adalah sama sebagai kisah yang direfleksikan setiap orang ketika membaca atau mendengar puisi tersebut. Ada banyak nilai yang mempunyai kekuatan dan rasa, mewakili semua manusia. ${ }^{32}$

Gereja terus berkembang untuk memperbaharui dirinya. Di mana genre puisi dengan genre apa pun dapat digunakan sebagai media penginjilan dalam bergereja untuk memberikan nilai-nilai hidup yang memelihara, menyembuhkan, dan melengkapi setiap orang untuk menjaga nilai-nilai Injil. Puisi dibangun dari realitas dengan tanggung jawab manusia dan Tuhan sebagai relasi manusia dan lingkungan. Puisi memberikan sesuatu nilai pemberitaan. Dalam puisi penyair telah cermat mengkomunikasikan nilai-nilai Injil yang menyatakan keberadaan Tuhan dalam hidup manusia. Puisi mampu menjadi media penginjilan yang tidak melawan Alkitab, tetapi puisi sebagai perwakilan kabar sukacita atau pemberitaan bagi semua orang yang berbeda latar belakang.

Morika Tetelepta sebagai penyair juga menyebutkan kekuatan puisi bagi penyair berada dalam keadaan tidak sadar, menuntut dan meminta pekerjaan Roh Kudus untuk membuatnya berkarya. Setiap puisi dan lagu yang dibuat penyair bertolakdari kekosongan. Dan untuk menerima sesuatu yang Ilahi, ia harus memasrahkan diri dan meminta Roh Kudur dari Tuhan. Hal tersebut membuat perjumpaan antara penyair dengan hal abstarak untuk manyadarkan ia atas kuasa yang lebih dari dirinya. ${ }^{33}$

Puisi menjadi pewartaan hidup demi keseimbangan dan kelimpahan. Puisi menghadirkan nilai-nilai Injil yang tidak terbatas pada teks melainkan pada artikulasi puisi secara lebih dalam nilai-nilai yang menggugat, mendorong, merangkul, mencintai atau membeci. Kebanyakan penyair menyatakan tatanan perjumpaan terjadi yang menjadi bentuk pemeliharaan antar hubungan dengan tidak menolak diri sebagai derajat ciptaan yang sama sebagai mahkluk Tuhan.

\section{d. Puisi Duang e Sebagai Media Penginjilan}

Kata-kata dalam puisi Duang e, terlampau mengandung unsur semiotik atau kekayaan "tanda" yang mempunyai arti lebih. Berdasarkan keutuhannya, puisi Duang e memiliki simbol-simbol ikonis atau sisitim metafora. Kerangka semiotik mengenai tanda mempunyai konvensi kata-kata yang kompleks sebagai pilihan nilai. Metafora puisi Duang e terkatagorikan bersama prinsip yang mewakili 
perasaan semua orang (bukan saja penyair). Di mana setiap refleksi dibangun dan dibentuk dari pemikiran penyair bahwa puisi Duang $e$ mengkomunikasikan pesan (nilai Injil). Ia mewartakan segala kelimpahan nilai hidup kepada seluruh manusia dengan cara memelihara nilai-nilai keilahian itu yang terimanen dalam keabsaan realitas.

Puisi Duang e, adalah realitas kedua yang menunjukkan kepada kekuatan, kekuasaan, keagungan, kemuliaan Tuhan sebagai hakekat transendensi. Sekelumit metafora-metafora dari puisi, mengorientasikan hubungan realitas pertama dan kedua antara hakekat Tuhan dan hakekat alam. Realitas Tuhan (realitas teologis), telah terimplementasikan dalam realitas nyata. Mampu membentuk satu media penginjilan yang memiliki nilai-nilai hidup (universalitas), bagi siapa saja. Bukan lagi orientasinya kepada kekayaan dan keindahan tanah Kei tetapi kepada pemenuhan kemanusiaan, keimanan dan pemenuhan ciptaan lain. Puisi Duang $e$ dalam bentuknya ia bersifat puisi hymne (bentuk puisi yang menggambarkan kesyaduan Tuhan). Pertunjukan puisi hymne mengacuh kepada kekayaan nilainilai ketuhanan yang selalu disentralkan.

Dalam puisi Duang e, penyair tetap mengsistematiskan rangkaian gaya bahasa dalam bentuk sintaksis yang teratur. Untuk menjawab apakah bisa puisi Duang e dipakai sebagai sebah media penginjilan maka dengan cermat kita harus bisa mengungkapkan makna puisi dalam sejumlah metafora-metafora yang digagas sang penyair. Duang $e$ memang penuh dengan deskripsi kritis dan evaluasi real. Ia menyatakan penginjilan yang mengandung nilai untuk dijelaskan demi memberitahukan tatanan ketuhanan nilai, kealaman nilai, nilai kemanusiaan ke dalam dunia nyata. Bahwa Allah berbuat melalui tindakan karya-Nya. Dia menambahkan realitas dirinya bersama manusia yang tampaknya mempunyai konvensi seni berdasarkan keseimbangan pemikiran. Misalnya, yang harus dipertimbangkan ketika mencoba mengkorelasi antara "teks" dalam puisi. Di mana fenomena nyata terintegral melalui pikiran, perasaan (keimanan dan kemanusiawi) dalam setiap orang, sehingga berguna untuk mengulas makna teks dan dapat diperlakukan menjadi keputusan nilai-nilai Injil.

Puisi Duang e telah menjadi hakekat bahasa manusia, pengalaman, dan imajinasi. Berkontribusi memperkaya manusia tanpa menyesatkan realitas dan berupaya mengupayakan pikiran "teo sentris". Aktivitas Ilahi di bawah keindahan 
nyata telah menyatakan keadaan dan merekonstruksi pemikiran kita secara baik. Sebagaimana keterbukaan dan ketergantungan pada bantuan intervensi Ilahi dan sebab-akibat budaya, agama, dalam ruang lingkup kosmologi.

Perspektif menginjili menegaskan bahwa kisah-kisah Alkitab yang menyajikan peristiwa dan karakter Yesus Kristus dan pendengar sebagai kebenaran sejarah. Ia menyampaikan kritik kebenaran ilahi sesuai dengan realitas budaya, agama, sosial setempat. Dengan menceritakan akurasi dan integritas peristiwa yang sebenar-benarnya terjadi. Tujuannya, mengisyaratkan seluruh kejadian dan rekaman yang sebenarnya terjadi dalam sejarah asasi manusia. Berada di satu netral keseimbangan antara realitas dan non realitas. Sama seperti pasangan kata-kata puitis, sifatnya saling melengkapi ruang dan waktu. Keajaiban fungsi paradigma keselamatan untuk memperlihatkan kebebasan seluruh keterikatan dan penindasan atas hak dan kewajiban manusia hak-hak alam.

Simbol-simbol dipakai untuk menimbulkan perjuangan dialektis nilai. Membentuk stabilitas kata-kata yang tidak menuding atau menuduh. Secara baik makna dibawakan dengan fungsi menginjili dalam bahasa dramatis. Mengisyaratkan aktivitas independen alam atau idenpenden Tuhan. Pengawasan penyair terhadap kata-kata memperlihatkan betapa nilai puitis dapat dipakai dalam pelayanan gereja (penginjilan), Roh Kuduslah (hikmat Tuhan) yang memberikan gambaran kemenangan puitis menjadi penginjilan yang hampir selalu diperlukan dalam rangka mengubah fakta-fakta mentah menjadi cerita. Fakta mentah sering tidak membuat cerita yang hidup dan bernafas. Penyair berupaya menggunakan konvensional tipe-adegan untuk membentuk matriks terhadap apa yang dipahami dengan menggunakan puisi supaya lebih menarik membawa beberapa imajinasi bekerja dalam komposisi iman. Meskipun manusiawi menyadari semua bahan dari gambar aslinya. Penyair merekonstruksi peristiwa kompleks yang sedemikian rupa mencerminkan akurat tindakan, kata-kata, dan pikiran protagonis atau pun antagonis manusia terhadap Tuhan.

Penggunaan bahasa artistic puisi Duang e berkontribusi terhadap kejelasan, dan drama dari cerita, yaitu prinsip dalam menjelaskan kisah puitis. Bahasa hidup mewarnai, mencegah setiap hal-hal negatif sesuai dengan setiap detail deskripsinya. Pola Bahasa puisi Duang e banyak menekankan pada efek dramatis, emosional, keromantisan sehingga pembaca dibiarkan menafsir lalu kagum, 
mengalami, memaknai, dan bisa mengambil nilai-nilai dari apa yang Tuhan telah lakukan di zaman lampau sampai sekarang.Pola puitis Duang e dan urutan kronologis menjadi satu penciptaan kesenian sastra, juga nilai Injil. Kesenian sastra atau struktur po-etik sebagai media penginjilan menegaskan inspirasi dan interaksi Firman Tuhan yang bergulat dengan hubungan antara historisitas dan kerajinan sastra untuk memperlakukan manusia yang memanusiakan yaitu memelihara nilai dan hidup.

\section{e. Puisi Memberitakan Kabar Sukacita Bagi seluruh ciptaan}

Puisi mampu memberikan ketegasan nilai-nilai imperatif penginjilan (keharusan) saat dibacakan dan diartikulasikan menjadi bermakna. Setiap nilainilai dalam puisi haruslah dituturkan ke dalam kesatuan nilai-nilai Injil dan penciptaan estetika seluruh ciptaan. Salah satunya Puisi Duang e yang bukanlah sekedar karya sastra belaka tetapi karya yang harus diekspresikan menjadi atributatribut tindakan menginjili atau memberitakan kabar sukacita, berdasarkan konteksnya. Setidaknya jangan sampai unsur-unsur Tuhan dalam puisi dipangkas dari iman dan dimensi lain (ketidakpedulian terhadap alam) atau pun keacuan sudut pandang bagi realitas untuk memaknai tatanan kosmologi dan kekuatan puisi.

Untuk memahami karya-karya lain yang merupakan imago dei Allah (penyangkalan terhadap manusia yang adalah mahkluk sempurna tanpa melihat kesempurnaan dan kebergantungan kepada mahkluk lain). Manusia dengan pasrah harus menyangkal dirinya sebagai manusia yang superioritas dan memiliki kehendak kekuasaan terhadap ciptaan lain. Allah dalam ciptaan-Nya telah meletakan dirinya menjadi hasil ciptaan lain bukan saja manusia. Alam dan Tuhan menjadi subtansi dari kehidupan. Ungkapan unsur-unsur ciptaan lain yang berada di luar manusia harus dijadikan sebagai imago dei Allah untuk menentukan sebuah pembebasan dan hekakat ciptaan yang tidak berhirarki. Penginjilan bukan saja memprioritaskan asumsi keimanan, kemanusiaan tetapi penginjilan yang ditegaskan dalam puisi Duang e yaitu gereja memampukan diri untuk berdiri, membangun tatanan relasi yang utuh antara seluruh ciptaan. Dalam puisi Duang $e$ penyair menempatkan Tuhan kita adalah Tuhan yang tidak jauh dari ciptaannya (Ia ada dalam realitas manusia dan alam). Tuhan terinternalisasi (menyatukan diri) dalam ciptaannya sehingga Tuhan benar-benar ada dan nyata. Tuhan (butir- 
butir surgawi) menempati butir-butir pasir dan kemilau ganggang laut adalah gereja yang harus bertumbuh mengubah ekspresi keimanannya yang terlalu menegaskan pada ritualistik (transendensi Tuhan). Gereja semestinya melihat Tuhan yang hidup dan Tuhan yang menghidupkan setiap ciptaan berdasarkan karya semesta. Penginjilan pun menjadi butir-butir pasir, lembayung, kemilau ganggang laut, keindahan lautan, pulau-pulau, dan rumput-rumput hijau. Sifat baik (keindahan, kemegahan) yang diluangkan penyair dalam puisinya menunjukkan gereja yang selamanya harus menghidupkan hakekat Tuhan pada kualitas memberi hidup (negeri matahari), memberi sukacita, keindahan dan berkat bagi setiap manusia. Manusia atau pun gereja dalam rotasi dan realitas kehidupan, ia harus mempergantungkan diri seutuhnya kepada Tuhan. Penyair mengungkapkan, (Kau beri aku...; minta ampun; Kau adalah rahim).

Orientasi gereja dalam memberi hidup (penginjilan) tidak harus berada hanya dalam lingkup Kristen (ingat tidak ada orang Yunani, Yahudi) yang ditegaskan oleh Paulus. Bahwa di dalam Yesus Kristus yang menjadi pusat penginjilan gereja. Kegiatan pemberitaan harus diorientasikan kepada semua manusia tanpa melihat status apa pun (hakiki tujuan penginjilan). Tetapi bukanlah semata-mata pemberitaan adalah pengkristenisasi, melainkan "kau berikan aku warna-warni" menerangkan penginjilan berdasarkan pemahaman untuk dapat melihat perbedaan sebagai kesatuan hidup dan saling memberikan warna kehidupan. Perbedaan tetap dihargai oleh gereja dan karena perbedaan maka Allah kita menjadi Allah yang dinamis dan terus bergerak menempuh batasanbatasan manusia. Tuhan telah melekat dalam kepelbagaian kosmologi. Di setiap unsur agama, budaya, suku, etnis, Tuhan tetap dipahami berdasarkan konteknya sendiri-sendiri. Gereja dalam penginjilan bukan melihat Tuhan dalam kacamata nilai-nilai khotbah tetapi realitas yang tak pernah sadar bahwa Tuhan ada di dalam kekayaan budaya dan keindahan alam, kekayaan dan keindahan perbedaan adalah manifestasi Tuhan yang agung dan mulia sekaligus anugerah Tuhan yang luas bagi manusia (warna-warni).

Sebagaimana pusat penginjilan adalah Yesus Kristus, gereja diperbaharui bukan mengandalkan keunggulannya. Gereja tidak lagi menjadi gereja yang angkuh mempertahankan dirinya sendiri sebagai totalitas diri yang paling benar sebab "pada jantungku yang gemetar" manusia itu sama adalah ciptaan Allah. 
Jika ia tidak mau memahami sebuah kehendak penginjilan, hari "mengerti" dan bukan sekedar "tahu" bahwa tanah ini (altar) adalah Tuhan. Di mana puisi Duang e menampilkan pesona dramatikal kemanusiaan (gerejawi) bahwa gereja seutuhnya memerlukan campur tangan Tuhan untuk menjalankan hidup bergereja. Gereja dan manusianya tidak bisa bebas hidup sendiri dan mempertahankan keangkuannya (biasa berdampak pada dosa) sehingga keangkuhan itu menimbulkan keterpisahan dengan Tuhan seperti Paulus, yang telah menampilkan dramatik Tuhan dan manusia. Dengan demikan seluruh realitas gereja karena Ia adalah Rahim, mewakilkan semua bentuk puisi yang layak untuk dilihat kembali makna puisi-puisi dan berupaya menemukan makna Injil. Sebab puisi bukan sekedar "puitis yang bernuansa gombal cinta" tetapi merupakan kekayaan makan yang tak terbatas di setiap koheren-koheren (berkesinambungan) makna lain yang baik berkaitan dengan manusia, ciptaan lain dan Tuhan..

\section{KESIMPULAN}

Nilai-nilai Injil yang mempunyai peran penting dalam proses penginjilan. Secara sadar dan tidak sadar, puisi Duang e sudah menempatkan nilai dan memelihara nilai-nilai hidup secara universal. Yang Bertujuan mewartakan kabar baik dan mewujudkan Kerajaan Allah tanpa ada sekat dan pembatas. Ruang-ruang metafora yang mempunyai ribuan makna dan arti, saling menciptakan ruang realitas yang nyata untuk manusia pahami sesuai nilai-nilai keindahan gaya bahasanya. Ditafsirkan bebas untuk merangkai estetika hidup (karya Allah yang Maha Indah). Tertutama untuk memberitakan sifat-sifat keilahian Allah yang nyata dalam misi gereja. Media penginjilan dalam puisi telah menghubungkan relasi antara umat bergama, budaya, ras, suka dalam keadaan sosial yang berbeda. Ada pun pilihan kata menjadi pilihan nilai yang dapat membentuk karakter dalam kesadaran kepelbagaian. Nilai-nilai simbolik, tanda, bunyi, irama, rima yang selaras berperan penting untuk menggerakan, mengartikan, mengarahkan dasardasar nilai Injil yang tertanggungjawab di hadapan Tuhan. Secara teologis, puisi mengandung nilai-nilai cinta kasih mampu menginjili manusia dengan cinta dan menyatakan realitas pertama (teologis) dengan menunjukan realitas kedua (ciptaan), sehingga manusia sadar untuk memelihara kehidupan nyata dan mewartakan nilai-nilai Injil (pengakuan iman). Puisi berupaya menciptakan 
jembatan pemahaman antara dua belah pihak atau lebih. Menghalangi dampak pertentangan dalam upaya bermisi mengenai kerejaan Allah karena autentitas sastra yang universal, sehingga kepada siapa saja, kapan saja, di mana saja. Artinya, puisi dapat diterima oleh semua kalangan dalam memperlihatkan kedamaian dan kepenuhan tanpa perdebatan.

\section{Endnotes :}

${ }^{1}$ Michael Riffatere, Semiotics of Poetry, (Bloomington \& London: Indiana University Press, 1978), hlm. 1-2.

${ }^{2}$ Rene Wellek dan Austin Warren, Theory of Harmondsworth, (Middlesex: Penguin Book, 1968), hlm. 142-50.

${ }^{3}$ Rachmat Djoko Pradopo, Pengkajian Puisi: Analisis Strata Norma dan Analisis Struktur dan Semiotika-Cet Ke-8, (Yogyakarta: Gadjah Mada University Press, 2002), hlm. 278.

${ }^{4}$ Ibid., hlm. 279.

${ }^{5}$ Metafora adalah kiasan atau gambaran. Semile adalah persamaan. Personifikasi adalah mengubah makna menjadi sifat peng-orangan. Metonim adalah memaksudkan sesuatu yang berdekatan.

${ }^{6}$ Rachmat Djoko Pradopo, Pengkajian Puisi: Analisis Strata Norma dan Analisis Struktur dan Semiotika-Cet Ke-8, (Yogyakarta: Gadjah Mada University Press, 2002), hlm. 6.

${ }^{7}$ Jan fokkelman, Menemukan Makan Puisi Alkitab:Penuntun Dalam Memahami Syair-Syair Alkitab Sebagai Karya Sastra, (BPK Gunung Mulia: Jakarta, 2009), hlm. 43.

${ }^{8}$ Ibid., hlm.2-3.

${ }^{9}$ Ibid., hlm. 37.

${ }^{10}$ Ibid., hlm. 37.

${ }^{11}$ Ibid., hlm. 38.

${ }^{12}$ Ibid., hlm. 38.

${ }^{13}$ Ibid., hlm. 29.

${ }^{14}$ Ibid., hlm.30.

${ }^{15}$ Ibid., hlm. 8-9.

${ }^{16}$ Ibid., hlm. 9.

${ }^{17}$ Ibid., hlm. xv.

${ }^{18}$ David J Bosch, Transformasi Misi Kristen; Sejarah Teologi Misi yang Mengubah dan Berubah, (BPK Gunung Mulia, Jakarta, 2005), hlm. 626-627.

${ }^{19}$ Ibid., hlm. 631-632.

${ }^{20}$ Ibid., hlm. 626-644.

${ }^{21}$ Harun Hadiwijono, Iman Kristen, (Jakarta: Gunung Mulia, 2010), hlm. 385-386.

${ }^{22}$ Ibid., hlm. 388.

${ }^{23}$ Ibid., hlm. 389-390.

${ }^{24}$ Yasraf Amir Piliang, Semiotika dan Hipersemiotika, (Bandung: Matahari, 2012), hlm. 300-309.

${ }^{25}$ Ibid., hlm. 312.

${ }^{26}$ John Fiske, Cultural and Communication Studies, (Yogyakarta: Jalasutra, 1990), hlm. 60-81.

${ }^{27}$ Yasraf Amir Piliang, Semiotika dan Hipersemiotika, (Bandung: Matahari, 2012), hlm. 300-315.

${ }^{28}$ Rene Wellek dan Austin Warren, Theory of Harmondsworth, (Middlesex: Penguin Book, 1968), hlm. 25.

${ }^{29}$ Hasil wawancara dengan R.F. Tanggal, 22 Juli 2013. Pukul 11:31, tempat: Rumah OSM, Kota Ambon.

${ }^{30}$ Hasil wawancara dengan M. D.,Tanggal, 10 Agustus 2013, Pukul 10:16, tempat: Area Tribun Lapangan Merdeka - Kota Ambon. 
${ }^{31}$ Hasil wawancara dengan R. F.,Tanggal, 22 Juli 2013. Pukul 11:31, tempat: Rumah OSM - Kota Ambon.

${ }^{32}$ Hasil wawancara dengan W. J.,Tanggal, 23 Juli 2013. Pukul 12:58, tempat: Kator Balitbang GPM - Kota Ambon.

${ }^{33}$ Hasil wawancara dengan M. T., Tanggal, 26 Juli 2013. Jam 15:13 WIT, tempat: Rumah Kopi Item di Danau Kopr - Kota Ambon.

\section{DAFTAR PUSTAKA}

Ahmad Shahnon, 1978. Penglibatan dalam Puisi. Kuala Lumpur: Utusan Publications \& Distrbutors.

Berlin Adele, 1994. Poetics and Interpretation of Biblical Narrative, Indiana: Eisenbrauns.

Bosch David J, 2005. Transformasi Misi Kristen, Jakarta: BPK Gunung Mulia.

Erikson, Millard J.,1998. Christian Theology, Michigan: Baker Academic Publisher.

Fiske John, 1990. Cultural and Communication, Terj. Yogyakarta: Jalasutra.

Fokkelman Jan, 2009. Menemukan Makan Puisi Alkitab; Penuntun Dalam Memahami Syair-Syair Alkitab Sebagai Karya Sastra: BPK Gunung Mulia, Jakarta.

Hadiwijono Harun, 2010. Iman Kristen, Jakarta: Gunung Mulia.

Keraf Gorys, 1984. Diksi dan Gaya Bahasa. Jakarta: Gramedia.

Kridalaksana Harimuriti, 1983. Kamus Lingustik. Jakarta: Gramedia.

Lembaga Alkitab Indonesia, 2002. Alkitab: perjanjian baru dan perjanjian lama. Jakarta: LAI

Randviir Anti, 2004. Mapping The World: Towards a Sociosemiotic Approach to Culture. Estonia: Tartu University.

Merrill Eugene H., 1995. History in Cracking Old Testament Codes: A Guide to Interpreting the Literary Genres of the Old Testament, Nashville: Broadman \& Holman.

Persekutuan Gereja-Gereja Di Indonesia, 2009. Keputusan Siding Raya XV PGI, Mamasa, Sulawesi Barat 19-23 November, Jakarta: PGI

Piliang Yasraf Amir, 2012. Semiotika dan Hipersemiotika, Bandung: Matahari. 
Pradopo Rachmat Djoko, 2002. Pengkajian Puisi: Analisis Strata Norma dan Analisis Struktur dan Semiotika, Yogyakarta: Gadjah Mada University Press.

Riffatere Michael, 1978. Semiotics of Poetry, Bloomington \& London: Indiana University Press.

Sailhamer John, 1995. Introduction to Old Testament Theology, Grand Rapids: Zon-dervan.

Teeuw A., 1980. Tergantung pada Kata, Jakarta: Pustaka Jaya.

Wellek Rene dan Austin Warren,1968. Theory of Literature. Harmondsworth, Middlesex: Penguin Book 